\title{
Tyrosine kinase inhibitors-induced hypothyroidism as a prognostic factor in metastatic renal cell carcinoma: a systematic review and meta-analysis
}

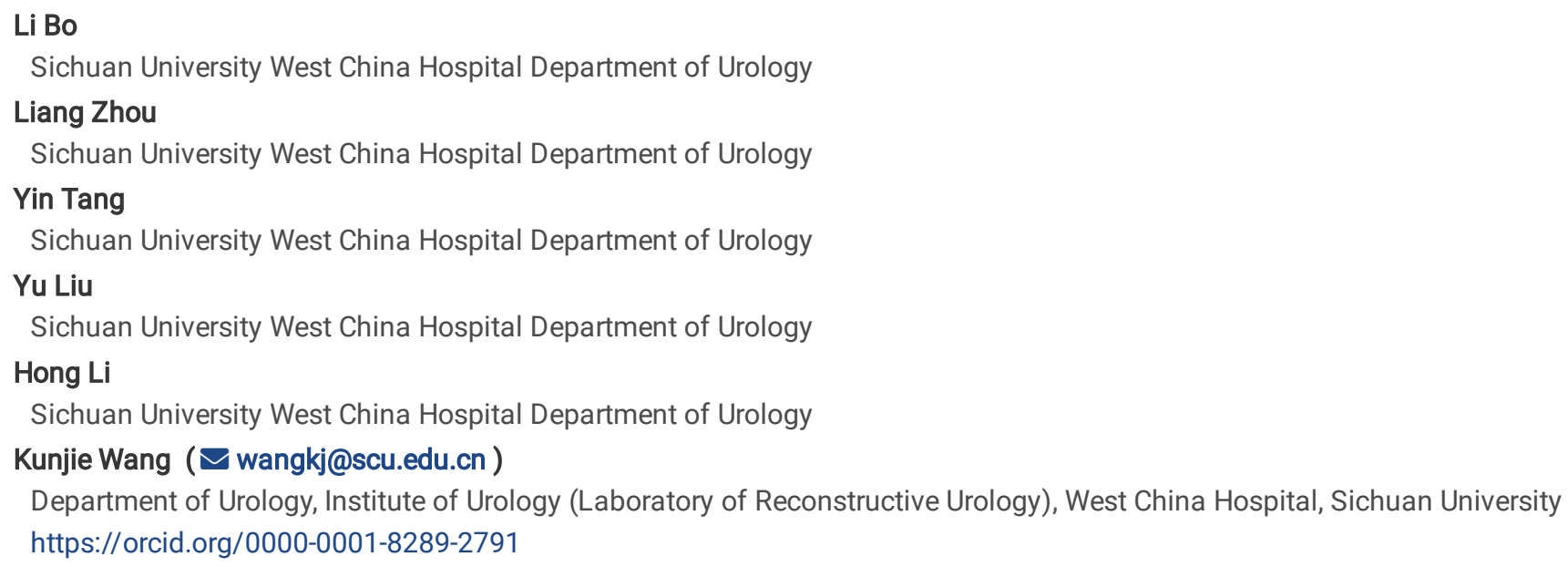

Research article

Keywords: renal cell carcinoma, hypothyroidism, tyrosine kinase inhibitors, meta-analysis

Posted Date: June 23rd, 2020

DOI: https://doi.org/10.21203/rs.3.rs-36842/v1

License: (ㄷ) This work is licensed under a Creative Commons Attribution 4.0 International License. Read Full License 


\section{Abstract \\ Background}

Hypothyroidism as a predictive factor represent highly controversial in patients with metastatic renal cell carcinoma (mRCC) with tyrosine kinase inhibitors-induced (TKI-induced) hypothyroidism. we aimed to evaluate the predictive value of TKI-induced hypothyroidism for progression-free survival (PFS) in patients with mRCC.

\section{Methods}

PubMed, Web of Science and Cochrane Library databases were searched with the keywords of "renal cell carcinoma", "hypothyroidism", "tyrosine kinase inhibitor", "sunitinib", "axitinib", "sorafenib" and "pazopanib" until September 2019. The hazard ratio (HR) and 95\% confidence interval (CI) of extracted from progression-free survival (PFS) were statistically analyzed by STATA15.1 software. Heterogeneity was assessed by $I^{2}$ value. Publication bias was appraised by the funnel chart, Egger's and Begg's tests.

\section{Results}

Eighteen studies with more than 1300 patients were included in this meta-analysis. The result demonstrated that TKI-induced hypothyroidism was an effective predictor of longer PFS (HR $\left.=0.57,95 \% \mathrm{Cl}: 0.49-0.66, \mathrm{P} \otimes 0.001, \mathrm{I}^{2}=34.4 \%\right)$ in patients with mRCC. No significant publication bias was detected.

\section{Conclusions}

Our analysis harvested from currently available clinical evidence shows that TKI-induced hypothyroidism expressed longer PFS, compared with euthyroidism, among patients with mRCC treated with "sunitinib", "axitinib", "sorafenib" and "pazopanib".

\section{Background}

At present, kidney neoplasm is the ninth most common cancer in men and the 14th most common cancer in women, and it is estimated that more than 1,000,000 people died of kidney cancer in 2012[1, 2].

Various researches have found that vascular endothelial growth factor receptor (VEGFR) tyrosine kinase receptor inhibitor (TKI), such as sunitinib, pazopanib, sorafenib, and axitinib, have a better curative effect on mRCC and can significantly prolong the survival time of patients[3, 4], which can be potential predictive biomarkers for therapeutic efficacy[5-8].

Researches have shown that PFS of thyroid dysfunction patients may not be as long as that of patients with normal thyroid function counterparts[9, 10], but some studies revealed that hypothyroidism is related to a longer PFS[11-13]. The relationship, however, between hypothyroidism caused by TKI and the prognosis of mRCC is still controversial. As a result, in this study, we attempted to evaluate the predictive value of TKI-induced hypothyroidism for PFS in patients with mRCC through this systematic review and meta-analysis.

\section{Methods}

\subsection{Search Strategy}

PubMed, Web of Science and the Cochrane Library database were searched by two researchers independently to find potentially eligible studies. The time frame spanned from the inception of each database to September 2019. The search keywords were: (renal cell carcinoma) AND [(tyrosine kinase inhibitor) OR sunitinib OR axitinib OR sorafenib OR pazopanib] AND (hypothyroidism). After that, the two researchers would analyze all the relevant literatures carefully and summarize the literature that met the included standard to avoid missing eligible literature.

\subsection{Inclusion and exclusion criteria}

Inclusion criteria: the literature was taken into account if they looked into the patients who suffered from mRCC and were treated with TKIs (sunitinib, pazopanib, sorafenib, and axitinib) and, were followed up long enough to gain effective data for patients with acquired hypothyroidism. Exclusion criteria: a. reviews, meta-analysis, letters, comments, case reports. b. The thyroid function of the patients was not 
tested for a long time. c. The literature did not provide hazard ratio (HR) of progression-free survival (PFS) in patients with normal thyroid function and hypothyroidism, nor do they have their Kaplan-Meier curve.

\subsection{Quality evaluation}

After reading the full text of included studies in detail, two researchers conducted the quality evaluation using the Newcastle-Ottawa Scale (NOS) with a total score of 9 . Generally, studies with a total score of 7 to 9,5 to 6 , and less than 4 were considered as high-quality, mediumquality and low-quality separately.

\subsection{Data collection and result evaluation}

Researchers extracted the following basic information, including the definition of hypothyroidism, first author, year, country, prior nephrectomy, study design, sample size, median follow-up, male/female ratio, median age, received treatment before, histology, interval time of thyroid function test, type of analysis, type of TKIs, number of patients with hypothyroidism and euthyroidism. The primary outcome was the HR and $95 \% \mathrm{Cl}$ of PFS between hypothyroidism patients and normal thyroid patients during TKIs treatment. In case of the absence of HR with confidence interval [Cls], we would calculate HR and confidence interval [Cls] based on the Kaplan-Meier curve according to the method described by Tierney et al.[14]. The definition of PFS is the same in all studies, defined as the time from the beginning of TKI treatment to disease progression or death. Most of the retrieved literature did not provide overall survival or did not follow up to the endpoint, so the relevant data were not collected.

\subsection{Statistical analysis}

For the time result of the event (PFS), we use STATA 15.1 software (College Station, Texas USA) to do the meta-analysis on the HR of PFS. For the results of meta-analysis, the cumulative HR value of $<1$ indicates a good prognosis of patients with metastatic renal cell carcinoma, and the $\mathrm{p}$-value of $<0.05$ is considered to be statistically significant. $\mathrm{I}^{2}$ index is used to evaluate heterogeneity. If $\mathrm{I}^{2}>40 \%$, it indicates that there is obvious heterogeneity, and the source of heterogeneity should be analyzed. Inversely, if $I^{2}<40 \%$, we think the heterogeneity of the study is acceptable. The application of fixed model and effect model is based on $\mathrm{I}^{2}<40 \%$ and $\mathrm{I}^{2}>40 \%$. Funnel chart and Egger's test, Begg's test are used to qualitatively and quantitatively analyze the publication bias.

\section{Results}

\subsection{Study selection}

Firstly, we searched the relevant databases according to the keywords. Then, we read the titles and abstracts of the retrieved literature one by one. After that, we carefully read the full text of the possible qualified literature and excluded unqualified literature. Finally, studies meeting the inclusion criteria were included in this study. The specific process is shown in Figure.1.

\subsection{Study characteristics and quality}

The baseline information is shown in Table 1. The year of publication of included studies is from 2010 to 2019 . Among these studies, four were prospective studies and 14 were retrospective studies. A total of 592 patients(43\%) suffered from hypothyroidism. The male/female ratio is between 1.6 and 4.9 , but four articles that did not provide a specific number of men and women. The median age was $59-69$, and one article did not provide the median age. More than $80 \%$ of patients underwent nephrectomy before being treated with TKIs. The definition of hypothyroidism during TKIs therapy was different among included studies slightly, including the National Cancer Institute Common Terminology Criteria for Adverse Events, the American Thyroid Association and the American Association of Clinical Endocrinologists, and thyroid serum hormone content. According to the quality score of the NOS, the score is between 6 and 7, which is shown in Table 2 . 
Table 1

Baseline characteristics of eligible studies

study study design sample size mean age TKls survival analysis type of analysis definition of hypothyroidism

\begin{tabular}{|c|c|c|c|c|c|c|c|}
\hline Baldazzi et al.[5] & $P$ & 22 & 61 & SUN & PFS & - & ATA and AACE \\
\hline Riesenbeck et al.[8] & $\mathrm{P}$ & 66 & 63 & SUN (63\%) SOR (37\%) & PFS & Multivariate & ATA and AACE \\
\hline Schmidinger et al.[7] & $\mathrm{R}$ & 87 & 64 & SUN (55\%) SOR (45\%) & PFS & - & $\mathrm{TSH}>3.77 \mu \mathrm{U} / \mathrm{mL}$ \\
\hline Sabatier et al.[6] & $P$ & 102 & 63 & SUN & PFS & Univariate & $\mathrm{TSH}>\mathrm{ULN}$ \\
\hline Fujita(a) et al. [9] & $\mathrm{R}$ & 41 & 64 & SUN & PFS & Univariate & NCI CTCAE,version 3.0 \\
\hline Sella et al. [10] & $\mathrm{R}$ & 31 & 69 & SUN & PFS & - & ATA and AACE \\
\hline Clemons et al. [26] & $\mathrm{R}$ & 56 & 60 & SUN (62\%) SOR (38\%) & PFS & - & $\mathrm{TSH}>5.0 \mathrm{mIU} / \mathrm{L}$ \\
\hline Kust et al. [27] & $\mathrm{R}$ & 41 & 60 & SUN & PFS & Univariate & $\mathrm{TSH}>4.0 \mathrm{mIU} / \mathrm{L}$ \\
\hline Fujita(b) et al.[28] & $\mathrm{R}$ & 44 & 64 & SUN & PFS & Univariate & NCI CTCAE, version 4.0. \\
\hline Bailey et al. [29] & $\mathrm{R}$ & 65 & 59 & SUN (80\%) SOR.PAZ.AXI (20\%) & PFS & Multivariate & $10 \mathrm{mlU} / \mathrm{L}>\mathrm{TSH}>\mathrm{ULN}$ \\
\hline Nagyivanyi et al. [30] & $\mathrm{R}$ & 274 & 62 & SUN & PFS & Multivariate & NCI CTCAE,version 3.0 \\
\hline Bozkurt et al. [31] & $\mathrm{R}$ & 81 & 60 & SUN & PFS & - & $\mathrm{TSH}>4.4 \mu \mathrm{lU} / \mathrm{mL}$ \\
\hline lacovelli et al. [32] & $\mathrm{R}$ & 104 & 62 & SUN (90.4\%) PAZ (9.6\%) & PFS & - & NCI CTCAE,version 3.0 \\
\hline Puente et al. [33] & $\mathrm{R}$ & 97 & - & SUN & PFS & Multivariate & NCI CTCAE,version 4.0 \\
\hline Buda-Nowak et al. [34] & $\mathrm{R}$ & 27 & 65 & SUN & PFS & Univariate & $\mathrm{TSH}>4.2 \mu \mathrm{lU} / \mathrm{mL}$ \\
\hline Takada et al. [35] & $\mathrm{R}$ & 44 & 67 & AXI & PFS & - & $\mathrm{TSH}>3.5 \mu \mathrm{lU} / \mathrm{mL}$ \\
\hline Bolzacchini et al. [36] & $\mathrm{R}$ & 145 & 63 & SUN & PFS & Multivariate & NCI CTCAE,version 4.0 \\
\hline Rizza et al. [37] & $\mathrm{P}$ & 42 & 61 & SUN & PFS & - & $\mathrm{TSH} \geq 5.0 \mu \mathrm{lU} / \mathrm{mL}$ \\
\hline
\end{tabular}

R Retrospective, P prospective, PFS Progression-free survival, ULN upper limit of normal, TKI tyrosine kinase inhibitor, ATA and AACE the American Thyroid Association and the American Association of Clinical Endocrinologists, NCI CTCAE the National Cancer Institute Common Terminology Criteria for Adverse Events, TSH Thyroid Stimulating Hormone, SUN Sunitinib, SOR Sorafenib, PAZ Pazopanib, AXI Axitinib, - No data was obtained in the article 


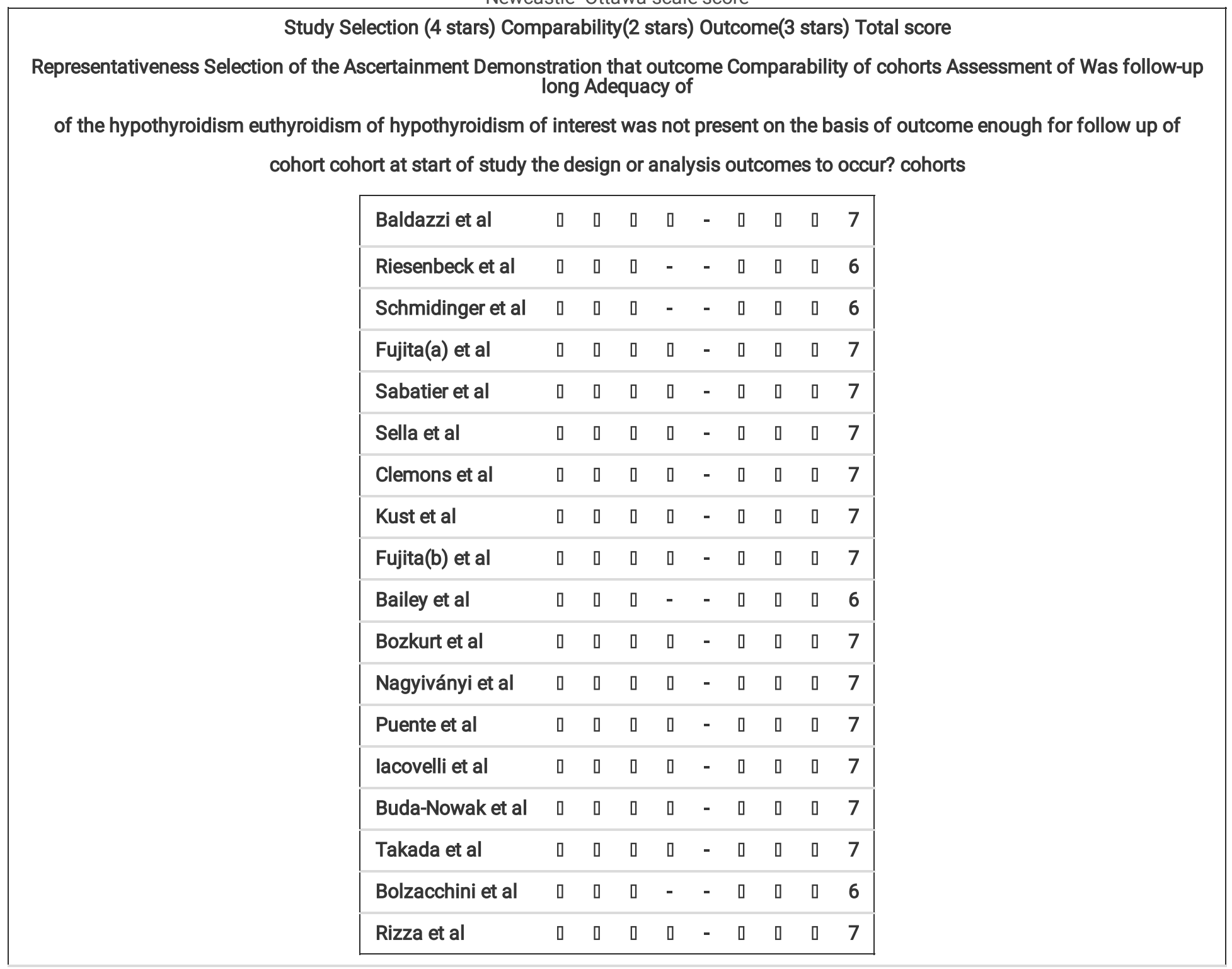

\subsection{Relationship between TKIs-induced hypothyroidism and PFS of advanced RCC patient}

The pooled-HR of the PFS is calculated and presented in Fig. 2. Hypothyroidism is positively correlated with longer PFS (HR $=0.57,95 \% \mathrm{Cl}$ : $0.49-0.66, \mathrm{P} \otimes 0.001$ ), which means that patients with hypothyroidism live longer without the progression of $\mathrm{mRCC} . \mathrm{I}^{2}=34.4 \%<40 \%$ shows that there is no obvious heterogeneity.

\subsection{Meta-regression analysis}

The outcome of meta-regression analysis is revealed in Table 3. These variations-year (adjusted $\mathrm{R}^{2}=9.31 \%, \mathrm{P}<0.01$ ), study design (adjusted $R^{2}=-8.97 \%, P<0.01$ ), sample size (adjusted $R^{2}=-7.36 \%, P=0.01$ ), definition of hypothyroidism (adjusted $R^{2}=-26.92 \%, P=$ 0.03 ), nephrectomy(\%) (adjusted $R^{2}=-39.70 \%, P=0.01$ ), histology(clear cell\%)(adjusted $\left.R^{2}=-45.75 \%, P=0.029\right)$, type of analysis(adjusted $R^{2}=$ $-52.05 \%, P=0.007)$, TKIs(adjusted $\left.R^{2}=17.18 \%, P=0.008\right)$ may bring about heterogeneity of inter-research, while others not $(P=0.05 \sim 0.157)$. 
Table 3

Subgroup and Meta-regression of pooled HR for PFS

\begin{tabular}{|c|c|c|c|c|c|c|c|c|c|c|c|}
\hline \multirow[t]{2}{*}{ Subgroup } & \multicolumn{2}{|c|}{ Pooled HR of PFS } & \multicolumn{2}{|c|}{ Heterogeneity } & \multicolumn{7}{|c|}{ Meta-regression } \\
\hline & $\begin{array}{l}\mathrm{HR}(95 \% \\
\mathrm{Cl})\end{array}$ & $\begin{array}{l}\mathrm{P} \\
\text { value }\end{array}$ & $I^{2}$ & $\begin{array}{l}\mathrm{P} \\
\text { value }\end{array}$ & $\begin{array}{l}\text { No.of } \\
\text { studies }\end{array}$ & Coefficient & $\begin{array}{l}\text { Standard } \\
\text { error }\end{array}$ & $\begin{array}{l}\mathrm{T} \\
\text { value }\end{array}$ & $\begin{array}{l}\mathrm{P} \\
\text { value }\end{array}$ & $\mathrm{Tau}^{2}$ & $\begin{array}{l}\text { Adjusted } \\
\mathrm{R}^{2}\end{array}$ \\
\hline Year & & & & & 18 & -0.623 & 0.125 & -4.98 & $\varangle 0.001$ & 0.039 & $9.31 \%$ \\
\hline 2010-2014 & $\begin{array}{l}0.51(0.33- \\
0.68)\end{array}$ & $\begin{array}{l}P< \\
0.001\end{array}$ & $0.00 \%$ & 0.537 & & & & & & & \\
\hline 2015-2019 & $\begin{array}{l}0.48(0.39- \\
0.57)\end{array}$ & $\begin{array}{l}P< \\
0.001\end{array}$ & $0.00 \%$ & 0.588 & & & & & & & \\
\hline Country & & & & & 18 & -0.410 & 0.194 & -2.12 & 0.050 & 0.052 & $-20.48 \%$ \\
\hline Europe, the USA & $\begin{array}{l}0.49(0.40- \\
0.58)\end{array}$ & $\begin{array}{l}P< \\
0.001\end{array}$ & $0.00 \%$ & 0.691 & & & & & & & \\
\hline Other country & $\begin{array}{l}0.47(0.30- \\
0.64)\end{array}$ & $\begin{array}{l}P< \\
0.001\end{array}$ & $5.50 \%$ & 0.381 & & & & & & & \\
\hline Study design & & & & & 18 & -0.537 & 0.114 & -4.72 & $\nabla 0.001$ & 0.047 & $-8.97 \%$ \\
\hline Prospective & $\begin{array}{l}0.49(0.20- \\
0.78)\end{array}$ & $\begin{array}{l}P= \\
0.001\end{array}$ & $0.00 \%$ & 0.429 & & & & & & & \\
\hline Retrospective & $\begin{array}{l}0.49(0.40- \\
0.57)\end{array}$ & $\begin{array}{l}P< \\
0.001\end{array}$ & $0.00 \%$ & 0.627 & & & & & & & \\
\hline Sample size & & & & & 18 & -0.484 & 0.126 & -3.85 & 0.001 & 0.046 & $-7.36 \%$ \\
\hline$<60$ & $\begin{array}{l}0.40(0.25- \\
0.55)\end{array}$ & $\begin{array}{l}P< \\
0.001\end{array}$ & $0.00 \%$ & 0.935 & & & & & & & \\
\hline$\geq 60$ & $\begin{array}{l}0.52(0.43- \\
0.62)\end{array}$ & $\begin{array}{l}P< \\
0.001\end{array}$ & $8.90 \%$ & 0.361 & & & & & & & \\
\hline $\begin{array}{l}\text { Definition of } \\
\text { hypothyroidism }\end{array}$ & & & & & 18 & -0.524 & 0.148 & -3.55 & 0.003 & 0.055 & $-26.92 \%$ \\
\hline NCI CTCAE & $\begin{array}{l}0.50(0.40- \\
0.60)\end{array}$ & $\begin{array}{l}P< \\
0.001\end{array}$ & $5.30 \%$ & 0.382 & & & & & & & \\
\hline $\begin{array}{l}\text { Other definition } \\
\text { criteria }\end{array}$ & $\begin{array}{l}0.47(0.34- \\
0.61)\end{array}$ & $\begin{array}{l}P< \\
0.001\end{array}$ & $0.00 \%$ & 0.693 & & & & & & & \\
\hline Media age(year) & & & & & 18 & -0.528 & 0.354 & -1.49 & 0.157 & 0.010 & $77.91 \%$ \\
\hline$<63$ & $\begin{array}{l}0.47(0.37- \\
0.57)\end{array}$ & $\begin{array}{l}P< \\
0.001\end{array}$ & $0.00 \%$ & 0.971 & & & & & & & \\
\hline$\geq 63$ & $\begin{array}{l}0.51(0.37- \\
0.65)\end{array}$ & $\begin{array}{l}P< \\
0.001\end{array}$ & $28.90 \%$ & 0.188 & & & & & & & \\
\hline $\begin{array}{l}\text { Gender } \\
\text { (male/female } \\
\text { ratio) }\end{array}$ & & & & & 18 & -0.466 & 0.271 & -1.72 & 0.106 & 0.059 & $-36.45 \%$ \\
\hline$<2.0$ & $\begin{array}{l}0.53(0.25- \\
0.82)\end{array}$ & $\begin{array}{l}P< \\
0.001\end{array}$ & $0.00 \%$ & 0.536 & & & & & & & \\
\hline$\geq 2.0$ & $\begin{array}{l}0.48(0.39- \\
0.57)\end{array}$ & $\begin{array}{l}P< \\
0.001\end{array}$ & $1.60 \%$ & 0.424 & & & & & & & \\
\hline Nephrectomy(\%) & & & & & 18 & -0.692 & 0.233 & -2.97 & 0.010 & 0.060 & $-39.70 \%$ \\
\hline$<90$ & $\begin{array}{l}0.48(0.38- \\
0.58)\end{array}$ & $\begin{array}{l}P< \\
0.001\end{array}$ & $11.80 \%$ & 0.340 & & & & & & & \\
\hline$\geq 90$ & $\begin{array}{l}0.55(0.37- \\
0.73)\end{array}$ & $\begin{array}{l}P< \\
0.001\end{array}$ & $0.00 \%$ & 0.491 & & & & & & & \\
\hline
\end{tabular}

NO. number, PFS Progression-free survival, HR hazard ratio, SUN Sunitinib, SOR Sorafenib, PAZ Pazopanib, AXI Axitinib, - No data was obtained in the article 


\begin{tabular}{|c|c|c|c|c|c|c|c|c|c|c|c|}
\hline \multirow{2}{*}{$\begin{array}{l}\text { Subgroup } \\
\text { Histology(clear } \\
\text { cell\%) }\end{array}$} & \multicolumn{2}{|c|}{ Pooled HR of PFS } & \multicolumn{2}{|c|}{ Heterogeneity } & \multicolumn{7}{|c|}{ Meta-regression } \\
\hline & & & & & 18 & -0.596 & 0.246 & -2.42 & 0.029 & 0.063 & $-45.77 \%$ \\
\hline$<90$ & $\begin{array}{l}0.50(0.39- \\
0.60)\end{array}$ & $\begin{array}{l}P< \\
0.001\end{array}$ & $2.90 \%$ & 0.398 & & & & & & & \\
\hline$\geq 90$ & $\begin{array}{l}0.49(0.32- \\
0.66)\end{array}$ & $\begin{array}{l}P< \\
0.001\end{array}$ & $0.00 \%$ & 0.510 & & & & & & & \\
\hline Type of analysis & & & & & 18 & -0.558 & 0.180 & -3.09 & 0.007 & 0.065 & $-52.05 \%$ \\
\hline Univariate & $\begin{array}{l}0.45(0.25- \\
0.64)\end{array}$ & $\begin{array}{l}P< \\
0.001\end{array}$ & $0.00 \%$ & 0.479 & & & & & & & \\
\hline Multivariate & $\begin{array}{l}0.49(0.38- \\
0.60)\end{array}$ & $\begin{array}{l}\mathrm{P}< \\
0.001\end{array}$ & $22.80 \%$ & 0.269 & & & & & & & \\
\hline TKls & & & & & 18 & -0.821 & 0.261 & -3.15 & 0.008 & 0.036 & $17.18 \%$ \\
\hline SUN & $\begin{array}{l}0.55(0.42- \\
0.69)\end{array}$ & $\begin{array}{l}P< \\
0.001\end{array}$ & $0.00 \%$ & 0.664 & & & & & & & \\
\hline AXI & $\begin{array}{l}0.34(0.07- \\
0.61)\end{array}$ & $\begin{array}{l}P= \\
0.014\end{array}$ & - & - & & & & & & & \\
\hline SUN or SOR & $\begin{array}{l}0.53(0.24- \\
0.81)\end{array}$ & $\begin{array}{l}P< \\
0.001\end{array}$ & $8.80 \%$ & 0.334 & & & & & & & \\
\hline SUN or PAZ & $\begin{array}{l}0.55(0.29- \\
0.82)\end{array}$ & $\begin{array}{l}P< \\
0.001\end{array}$ & - & - & & & & & & & \\
\hline $\begin{array}{l}\text { SUN or SOR or } \\
\text { PAZ or AXI }\end{array}$ & $\begin{array}{l}0.44(0.31- \\
0.57)\end{array}$ & $\begin{array}{l}P< \\
0.001\end{array}$ & - & - & & & & & & & \\
\hline
\end{tabular}

\subsection{Subgroup analysis}

Subgroup analysis was showed in Table.3. Publication year, study design, sample size, definition of hypothyroidism, nephrectomy (\%), histology (clear cell\%), and type of analysis of these variations could alter subgroup heterogeneity. What is more, expect TKIs subgroup of Sunitinib or Sorafenib, patients who suffer from TKI-induced hypothyroidism in other TKIs subgroups have longer PFS(Figure.2).

\subsection{Publication bias}

Funnel chart (Fig. 3), Egger's and Begg's tests were used to evaluate publication bias. The funnel chart is not symmetrical and there may be publication bias. Egger's and Begg's tests are executed. Egger's test $(p=0.336)$, Begg's test $(p=0.596)$. Publication bias is not perceived in the face of statistical evidence.

\section{Discussion}

We found that patients with mRCC who take TKI drugs with hypothyroidism complications have longer PFS. TKI-induced hypothyroidism could act as a role to predict the prognosis in patients mRCC. TKIs-induced hypothyroidism, meanwhile, can help urologists and oncologists evaluate the efficacy of the TKI drugs to some degree.

The cause of hypothyroidism in patients with mRCC caused by the use of TKI drugs is very complicated. The VEGF and VEGFR are expressed in normal thyroid cells and thyroid follicles, which are mediated by thyrotropin to some extent $[15,16]$. TKI drugs inhibit the formation of VEGF and VEGFR expressed in normal thyroid cells[17]. At the same time, the thyroid is rich in capillaries, and its growth needs to be mediated by VEGF receptors on the surface of vascular endothelial cells, but TKI drugs inhibit the expression of VEFG and inhibit the formation and growth of capillaries. Insufficient blood supply leads to thyroid atrophy and decline in function[18]. Besides, the inhibition of thyroid peroxidase activity caused by TKI drugs leads to a decrease in thyroid hormone synthesis[19].

There is evidence that TKI drug may heighten anti-tumor immunity by regulating tumor microenvironment and increasing the expression of interferon (IFN)- $\gamma$, which may be beneficial to T cell activation and helper T cell type 1 cell-mediated response[20]. However, the activation of immune system may also be the pathophysiological mechanism of acquired hypothyroidism. Moreover, lymphocytic thyroiditis was found in patients with thyroid dysfunction during TKI drugs treatment [21]. In the above hypothesis, hypothyroidism and efficacy of TKI are two different manifestations in the treatment of mRCC. 
We found that the following factors may cause changes in thyroid function as well. There is a transition period to avoid the influence of thyroid function, although some patients received cytokine therapy before applied TKI drugs in the literature included in the meta-analysis[7].

The dose of TKI drugs used by different patients will be adjusted according to condition, which might be related to hypothyroidism. And most patients underwent repeated CT scans with intravenous iodinated contrast media every eight weeks. lodine-containing contrast media can temporarily increase serum TSH[22].

It is worth saying that the emergence of hyperthyroidism is not the eventual purpose. On the contrary, we should treat it in time in the course treatment. But it is controversial that the treatment of hypothyroidism based on serum TSH or clinical symptoms of hypothyroidism. Torino et al. documented that patients should receive thyroid hormone replacement therapy whenever thyrotropin exceeds $10 \mu$ IU / mL[23]. However, it is also found that some patients with obvious symptoms of hypothyroidism should be actively treated even if the concentration of TSH is not greater than $10 \mu \mathrm{IU} / \mathrm{mL}[24,25]$. There is a flexible question about the timing of intervention for hypothyroidism. Clinicians should consider comprehensively the wishes of patients, clinical symptoms and serum TSH levels.

Some shortcomings are presented in our study. First of all, the definition of hypothyroidism is not consistent completely in the included literature. Besides, our research has incorporated more retrospective literature. Of course, some advantages exist in our research. First, we carefully read the literature that may meet the standard, and when we find that the literature data that meet the standard is insufficient, we improve the relevant data by contacting corresponding authors or using the statistical methods of Tierney and others to ensure that they do not lose any articles that meet the conditions. And, researchers strictly select qualified articles according to our standards.

\section{Conclusions}

In summary, our analysis of currently available clinical evidence shows that TKIs-induced hypothyroidism during TKIs treatment can predict longer PFS, in metastatic RCC patients, especially sunitinib.

\section{Declarations}

\section{Authors' contributions:}

Bo Li was mainly responsible for the design of the work, the acquisition and analysis of data and manuscript writing. Liang Zhou carried out the acquisition of data. Yin Tang and YuLiu participated in the analysis of data. Kunjie Wang and Hong Li revised the manuscript. All authors read and approved the final manuscript.

\section{Funding}

This study was funded by 1.3.5 project for disciplines of excellence, West China Hospital, Sichuan University (ZY2016104. ZYGD18011) and The National Nature Science Fund of China (81770703).

\section{Conflict of interest:}

the author declares that they have no conflict of interest.

\section{Availability of data and materials:}

The datasets used and/or analysed during the current study available from the corresponding author on reasonable request.

\section{Ethics approval and consent to participate:}

All analyses were based on previous published studies. Thus, no ethical approval and patient consent are required.

\section{Acknowledgement]}

Not applicable.

\section{References}

1. Escudier B, Albiges L, Sonpavde G. Optimal management of metastatic renal cell carcinoma: current status. Drugs. 2013;73(5):427-38. doi:10.1007/s40265-013-0043-1.

2. Znaor A, Lortet-Tieulent J, Laversanne M, Jemal A, Bray F. International variations and trends in renal cell carcinoma incidence and mortality. Eur Urol. 2015;67(3):519-30. doi:10.1016/j.eururo.2014.10.002. 
3. Rock EP, Goodman V, Jiang JX, Mahjoob K, Verbois SL, Morse D, Dagher R, Justice R, Pazdur R. Food and Drug Administration drug approval summary: Sunitinib malate for the treatment of gastrointestinal stromal tumor and advanced renal cell carcinoma. Oncologist. 2007;12(1):107-13. doi:10.1634/theoncologist.12-1-107.

4. Goodman VL, Rock EP, Dagher R, Ramchandani RP, Abraham S, Gobburu JV, Booth BP, Verbois SL, Morse DE, Liang CY, Chidambaram N, Jiang JX, Tang S, Mahjoob K, Justice R, Pazdur R. Approval summary: sunitinib for the treatment of imatinib refractory or intolerant gastrointestinal stromal tumors and advanced renal cell carcinoma. Clin Cancer Res. 2007;13(5):1367-73. doi:10.1158/1078-0432.CCR06-2328.

5. Baldazzi V, Tassi R, Lapini A, Santomaggio C, Carini M, Mazzanti R. The impact of sunitinib-induced hypothyroidism on progression-free survival of metastatic renal cancer patients: a prospective single-center study. Urol Oncol. 2012;30(5):704-10. doi:10.1016/j.urolonc.2010.07.015.

6. Sabatier R, Eymard JC, Walz J, Deville JL, Narbonne H, Boher JM, Salem N, Marcy M, Brunelle S, Viens P, Bladou F, Gravis G. Could thyroid dysfunction influence outcome in sunitinib-treated metastatic renal cell carcinoma? Ann Oncol. 2012;23(3):714-21. doi:10.1093/annonc/mdr275.

7. Schmidinger M, Vogl UM, Bojic M, Lamm W, Heinzl H, Haitel A, Clodi M, Kramer G, Zielinski CC. Hypothyroidism in patients with renal cell carcinoma: blessing or curse? Cancer. 2011;117(3):534-44. doi:10.1002/cncr.25422.

8. Riesenbeck LM, Bierer S, Hoffmeister I, Kopke T, Papavassilis P, Hertle L, Thielen B, Herrmann E. Hypothyroidism correlates with a better prognosis in metastatic renal cancer patients treated with sorafenib or sunitinib. World J Urol. 2011;29(6):807-13. doi:10.1007/s00345010-0627-2.

9. Fujita T, Iwamura M, Ishii D, Tabata K, Matsumoto K, Yoshida K, Baba S. C-reactive protein as a prognostic marker for advanced renal cell carcinoma treated with sunitinib. Int J Urol. 2012;19(10):908-13. doi:10.1111/j.1442-2042.2012.03071.x.

10. Sella A, Hercbergs $A H$, Hanovich $E$, Kovel S. Does sunitinib-induced hypothyroidism play a role in the activity of sunitinib in metastatic renal cell carcinoma? Chemotherapy. 2012;58(3):200-5. doi:10.1159/000337079.

11. Czarnecka AM, Sobczuk P, Korniluk J, Spychalska M, Bogusz K, Owczarek A, Brodziak A, Labochka D, Moszczuk B, Szczylik C. Long-term response to sunitinib: everolimus treatment in metastatic clear cell renal cell carcinoma. Future Oncol. 2017;13(1):31-49. doi:10.2217/fon-2016-0355.

12. Vasileiadis T, Chrisofos M, Safioleas M, Kontzoglou K, Papazisis K, Sdrolia A. Impact of sunitinib-induced hypothyroidism on survival of patients with metastatic renal cancer. BMC Cancer. 2019;19(1):407. doi:10.1186/s12885-019-5610-8.

13. Nearchou A, Valachis A, Lind P, Akre O, Sandstrom P. Acquired Hypothyroidism as a Predictive Marker of Outcome in Patients With Metastatic Renal Cell Carcinoma Treated With Tyrosine Kinase Inhibitors: A Literature-Based Meta-Analysis. Clin Genitourin Cancer. 2015;13(4):280-6. doi:10.1016/j.clgc.2014.10.002.

14. Tierney JF, Stewart LA, Ghersi D, Burdett S, Sydes MR. Practical methods for incorporating summary time-to-event data into metaanalysis. Trials. 2007;8:16. doi:10.1186/1745-6215-8-16.

15. Hoffmann S, Glaser S, Wunderlich A, Lingelbach S, Dietrich C, Burchert A, Muller H, Rothmund M, Zielke A. Targeting the EGF/VEGF-R system by tyrosine-kinase inhibitors-a novel antiproliferative/antiangiogenic strategy in thyroid cancer. Langenbecks Arch Surg. 2006;391(6):589-96. doi:10.1007/s00423-006-0104-y.

16. Keefe SM, Cohen MA, Brose MS. Targeting vascular endothelial growth factor receptor in thyroid cancer: the intracellular and extracellular implications. Clin Cancer Res. 2010;16(3):778-83. doi:10.1158/1078-0432.CCR-08-2743.

17. Mendel DB, Laird AD, Xin X, Louie SG, Christensen JG, Li G, Schreck RE, Abrams TJ, Ngai TJ, Lee LB, Murray LJ, Carver J, Chan E, Moss KG, Haznedar JO, Sukbuntherng J, Blake RA, Sun L, Tang C, Miller T, Shirazian S, McMahon G, Cherrington JM. In vivo antitumor activity of SU11248, a novel tyrosine kinase inhibitor targeting vascular endothelial growth factor and platelet-derived growth factor receptors: determination of a pharmacokinetic/pharmacodynamic relationship. Clin Cancer Res. 2003;9(1):327-37.

18. Sato S, Muraishi K, Tani J, Sasaki Y, Tokubuchi I, Tajiri Y, Yamada K, Suekane S, Miyajima J, Matsuoka K, Hiromatsu Y. Clinical characteristics of thyroid abnormalities induced by sunitinib treatment in Japanese patients with renal cell carcinoma. Endocr J. 2010;57(10):873-80. doi:10.1507/endocrj.k10e-130.

19. Wong E, Rosen LS, Mulay M, VanVugt A, Dinolfo M, Tomoda C, Sugawara M, Hershman JM. Sunitinib induces hypothyroidism in advanced cancer patients and may inhibit thyroid peroxidase activity. Thyroid. 2007;17(4):351-5. doi:10.1089/thy.2006.0308.

20. Ozao-Choy J, Ma G, Kao J, Wang GX, Meseck M, Sung M, Schwartz M, Divino CM, Pan PY, Chen SH. The novel role of tyrosine kinase inhibitor in the reversal of immune suppression and modulation of tumor microenvironment for immune-based cancer therapies. Cancer Res. 2009;69(6):2514-22. doi:10.1158/0008-5472.CAN-08-4709.

21. Grossmann M, Premaratne E, Desai J, Davis ID. Thyrotoxicosis during sunitinib treatment for renal cell carcinoma. Clin Endocrinol (Oxf). 2008;69(4):669-72. doi:10.1111/j.1365-2265.2008.03253.x.

Page $9 / 13$ 
22. Wolter P, Stefan C, Decallonne B, Dumez H, Bex M, Carmeliet P, Schoffski P. The clinical implications of sunitinib-induced hypothyroidism: a prospective evaluation. Br J Cancer. 2008;99(3):448-54. doi:10.1038/sj.bjc.6604497.

23. Torino F, Barnabei A, Paragliola R, Baldelli R, Appetecchia M, Corsello SM. Thyroid dysfunction as an unintended side effect of anticancer drugs. Thyroid. 2013;23(11):1345-66. doi:10.1089/thy.2013.0241.

24. Muriel C, Esteban E, Corral N, Fonseca PJ, Luque M, Berros JP, Fernández Y, Blay P, Fra J, Villanueva N, Sanmamed M, Pardo P, Izquierdo M, Vieitez JM, Estrada E, Lacave ÁJ. Impact of the incorporation of tyrosine kinase inhibitor agents on the treatment of patients with a diagnosis of advanced renal cell carcinoma: study based on experience at the Hospital Universitario Central de Asturias. Clin Transl Oncol. 2010;12(8):562-7. doi:10.1007/s12094-010-0554-0.

25. Bianchi L, Rossi L, Tomao F, Papa A, Zoratto F, Tomao S. Thyroid dysfunction and tyrosine kinase inhibitors in renal cell carcinoma. Endocr Relat Cancer. 2013;20(5):R233-45. doi:10.1530/erc-13-0201.

26. Clemons J, Gao D, Naam M, Breaker K, Garfield D, Flaig TW. Thyroid dysfunction in patients treated with sunitinib or sorafenib. Clin Genitourin Cancer. 2012;10(4):225-31. doi:10.1016/j.clgc.2012.08.002.

27. Kust D, Prpic M, Murgic J, Jazvic M, Jaksic B, Krilic D, Bolanca A, Kusic Z. Hypothyroidism as a Predictive Clinical Marker of Better Treatment Response to Sunitinib Therapy. Anticancer Res. 2014;34(6):3177-84.

28. Fujita T, Wakatabe Y, Matsumoto K, Tabata KI, Yoshida K, Iwamura M. Leukopenia as a Biomarker of Sunitinib Outcome in Advanced Renal Cell Carcinoma. Anticancer Res. 2014;34(7):3781-7.

29. Bailey EB, Tantravahi SK, Poole A, Agarwal AM, Straubhar AM, Batten JA, Patel SB, Wells CE, Stenehjem DD, Agarwal N. Correlation of degree of hypothyroidism with survival outcomes in patients with metastatic renal cell carcinoma receiving vascular endothelial growth factor receptor tyrosine kinase inhibitors. Clin Genitourin Cancer. 2015;13(3):e131-7. doi:10.1016/j.clgc.2014.11.002.

30. Nagyivanyi K, Budai B, Biro K, Gyergyay F, Noszek L, Kuronya Z, Nemeth H, Nagy P, Geczi L. Synergistic Survival: A New Phenomenon Connected to Adverse Events of First-Line Sunitinib Treatment in Advanced Renal Cell Carcinoma. Clin Genitourin Cancer. 2016;14(4):314-22. doi:10.1016/j.clgc.2015.11.016.

31. Bozkurt O, Karaca H, Hacibekiroglu I, Kaplan MA, Duzkopru Y, Uysal M, Berk V, Inanc M, Duran AO, Ozaslan E, Ucar M, Ozkan M. Is sunitinib-induced hypothyroidism a predictive clinical marker for better response in metastatic renal cell carcinoma patients? $\mathrm{J}$ Chemother. 2016;28(3):230-4. doi:10.1179/1973947815Y.0000000039.

32. lacovelli R, Verri E, Cossu Rocca M, Aurilio G, Cullura D, de Cobelli O, Nole F. Prognostic role of the cumulative toxicity in patients affected by metastatic renal cells carcinoma and treated with first-line tyrosine kinase inhibitors. Anticancer Drugs. 2017;28(2):206-12. doi:10.1097/CAD.0000000000000439.

33. Puente J, Lainez N, Duenas M, Mendez-Vidal MJ, Esteban E, Castellano D, Martinez-Fernandez M, Basterretxea L, Juan-Fita MJ, Anton L, Leon L, Lambea J, Perez-Valderrama B, Vazquez S, Suarez C, Del Muro XG, Gallardo E, Maroto JP, Samaniego ML, Suarez-Paniagua B, Sanz J, Paramio JM, Sogug. Novel potential predictive markers of sunitinib outcomes in long-term responders versus primary refractory patients with metastatic clear-cell renal cell carcinoma. Oncotarget. 2017;8(18):30410-21. doi:10.18632/oncotarget.16494.

34. Buda-Nowak A, Kucharz J, Dumnicka P, Kuzniewski M, Herman RM, Zygulska AL, Kusnierz-Cabala B. Sunitinib-induced hypothyroidism predicts progression-free survival in metastatic renal cell carcinoma patients. Med Oncol. 2017;34(4):68. doi:10.1007/s12032-017-0928$z$.

35. Takada S, Hashishita H, Nagamori S, Endo M. Axitinib-Induced Hypothyroidism as a Predictor of Long-Term Survival in Patients with Metastatic Renal Cell Carcinoma. Urol Int. 2019;102(4):435-40. doi:10.1159/000499089.

36. Bolzacchini E, Pinotti G, Bertu L, Verusio C, Galli L, Mumoli N, Barbara C, Danova M, Bregni M, Artale S, Rossini C, Nigro O, Antonuzzo A, Derosa L, Torchio M, Barzaghi S, Ricci I, Suter M, Ballerio A, Vallini I, Dentali F. On-target Toxicities Predictive of Survival in Metastatic Renal Cell Carcinoma (mRCC) Treated With Sunitinib: A Multicenter Retrospective Study. Clin Genitourin Cancer. 2019. doi:10.1016/j.clgc.2019.10.003.

37. Rizza L, Sbardella E, Gianfrilli D, Lauretta R, Tenuta M, Del Bene G, Longo F, Faggiano A, Lenzi A, Giannetta E, Pozza C. Thyroid profile during the alternative Sunitinib dosing 2/1 schedule in metastatic renal cell carcinoma. Endocrine. 2019. doi:10.1007/s12020-01902088-4.

\section{Figures}




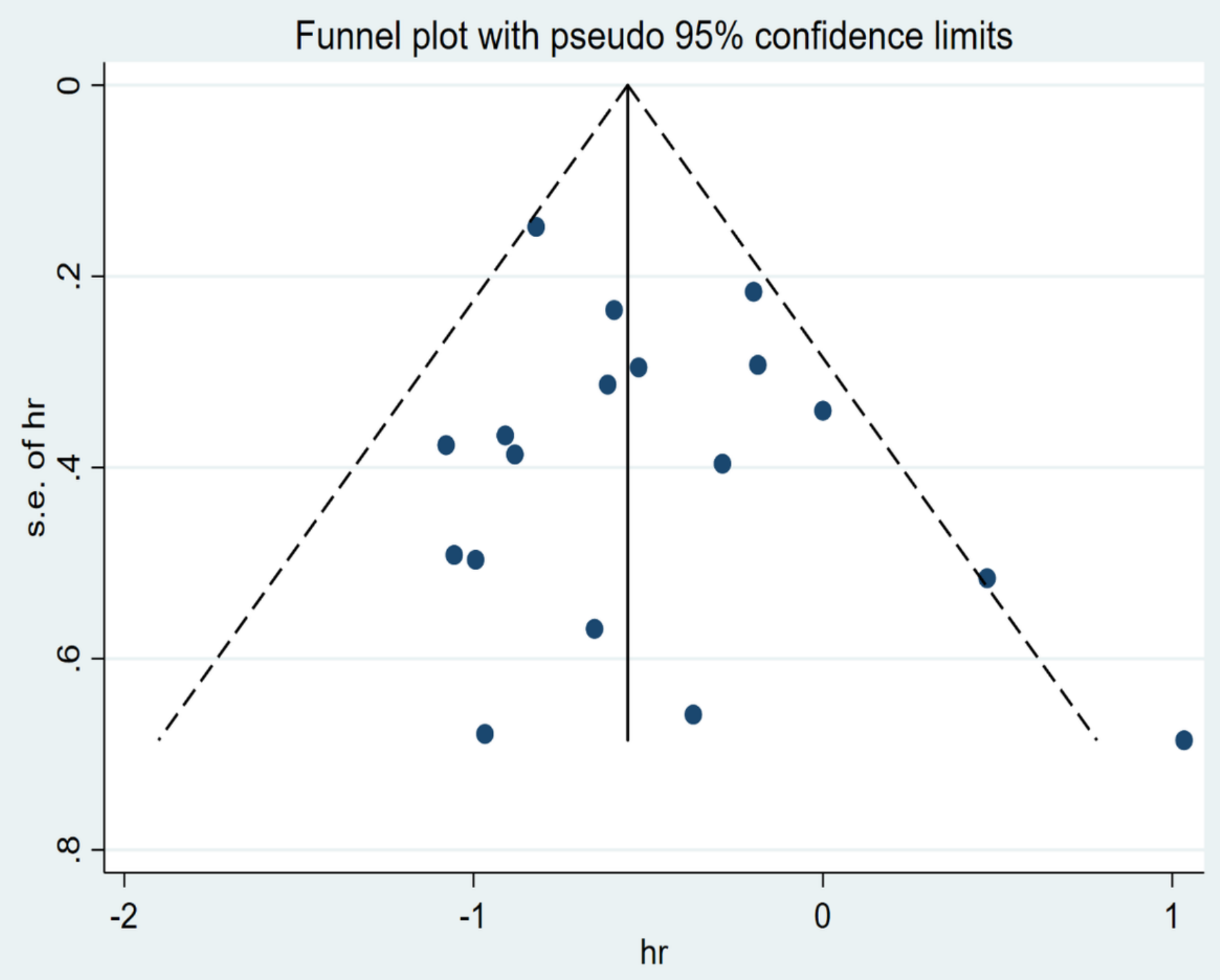

Figure 1

Funnel chart for testing publication bias. 


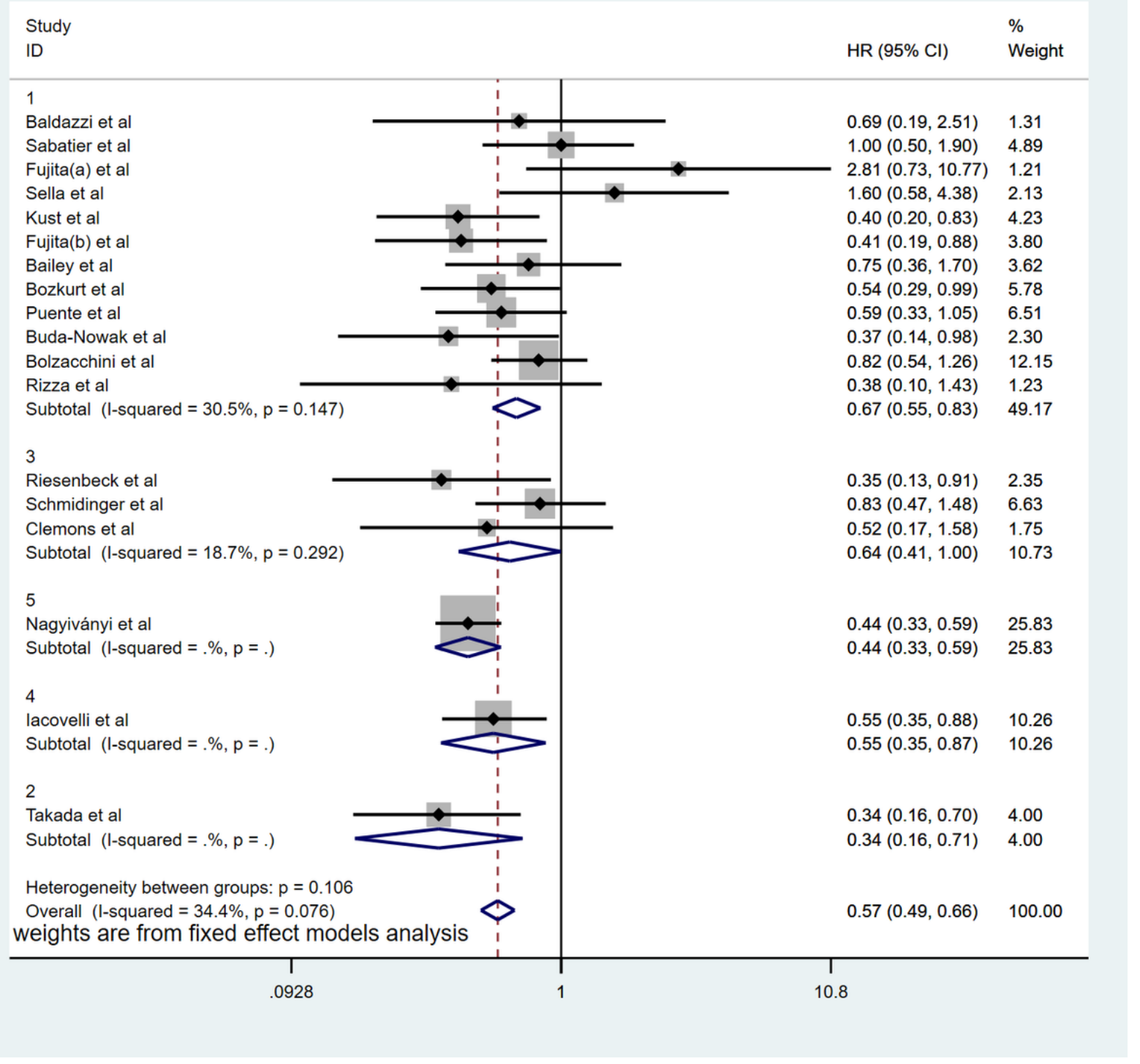

Figure 2

Forest plot reflects the progression-free survival of patients who were treated with different TKIs and developed hypothyroidism versus euthyroid patients (1: Sunitinib,2: Axitinib,3: Sunitinib or Sorafenib,4: Sunitinib or Pazopanib,5: Sunitinib or Axitinib or Sorafenib or Pazopanib). 


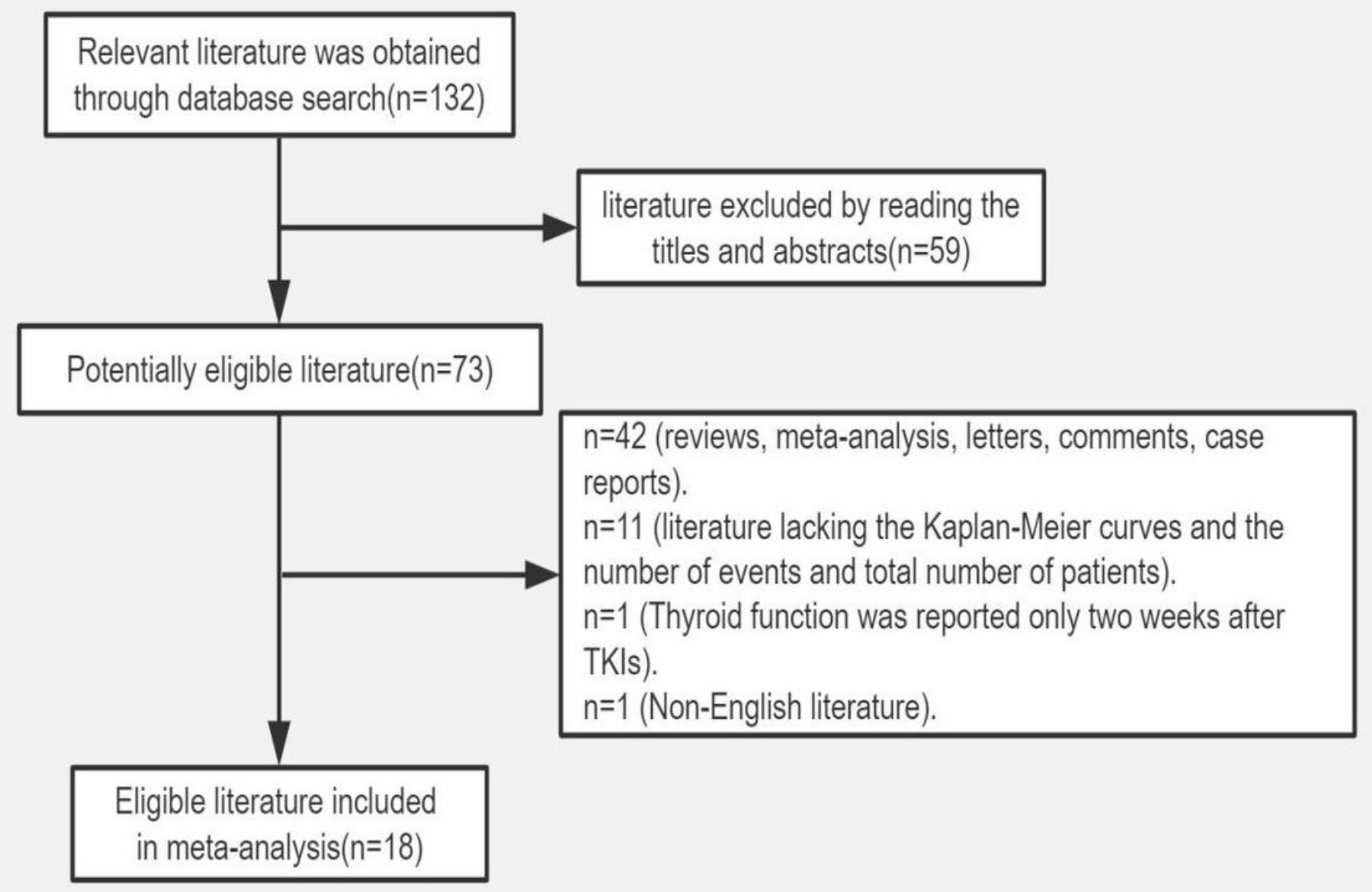

Figure 3

Flow Chart of document Retrieval and reasons for exclusion criteria. 